\title{
Sphingosine Kinase 2 Inhibitor Accelerates Fas-Mediated Cell Death Progression in A20/2J Cells
}

\author{
Miki Hara-Yokoyama*, ${ }^{,}$, Kazue Terasawa ${ }^{1}$, Akio Kihara ${ }^{2}$, Jin-Wook Kim²,3, Chan-Seo Park ${ }^{2,4}$, \\ Yoshio Hirabayashi ${ }^{5}$, Yasuyuki Igarashi ${ }^{2}$ and Masaki Yanagishita ${ }^{1}$
}

\begin{abstract}
${ }^{I}$ Department of Hard Tissue Engineering, Biochemistry, Division of Bio-Matrix, Graduate School, Tokyo Medical and Dental University, 1-5-45 Yushima, Bunkyo, Tokyo 113-8549, Japan, ${ }^{2}$ Department of Biomembrane and Biofunctional Chemistry, Graduate School of Pharmaceutical Sciences, Hokkaido University, Kita 12-jo, Nishi 6-choume, Kita-ku, Sapporo 060-0812, Japan, ${ }^{3}$ LCS biotech, 3-26, Pil-dong, Chung-gu, Seoul 100-715, Korea, (Present address) ${ }^{4}$ Department of Chemical and Biochemical Engineering, Dongguk University, 3-26, Pil-dong, Chung-gu, Seoul 100-715, Korea (Present address) and ${ }^{5}$ Brain Science Institute, The Institute of Physical and Chemical Research (Riken), 2-1 Hirosawa, Wako, Saitama 351-0198, Japan
\end{abstract}

\begin{abstract}
A sphingosine kinase (SPHK) type 2 inhibitor, SG-12, inhibited the SPHK2 activity in A20/2J cells and promoted Fas-dependent cell death. The effect of SG-12 on cell death was relieved by SPHK2 transfection but not by SPHK1 transfection. The results suggest a SPHK2-specific suppression of Fas-dependent cell death.
\end{abstract}

Key Words: Sphingosine-1-phosphate, Sphingosine kinase 2, Fas, Cell death, B cell.

\section{INTRODUCTION}

Sphingosine kinase (SPHK) catalyzes the phosphorylation of sphingosine to generate sphingosine-1-phosphate (S1P). The two mammalian isoforms of sphingosine kinase, SPHK1 [1] and SPHK2 [2], are different in their amino acid sequences, catalytic properties, intracellular localization, and tissue distribution [3]. Mice lacking SPHK1 [4], SPHK2 [5], or both [6] indicated that the functions of SPHK1 and SPHK2 are redundant in terms of their maintenance of extracellular S1P levels to support S1P-receptor mediated processes such as vascular maturation/angiogenesis [7-11], heart development [12], and lymphocyte trafficking [13]. On the other hand, it has been suggested that SPHK1 and SPHK2 have distinct roles in regulating cell survival and death [14], where S1P probably acts intracellularly [14,15]. Although SPHK1 has been shown to promote cell survival, several reports suggested that SPHK2 induces apoptosis [16] or inhibits cell growth [17]. T cells from mice lacking SPHK2 exhibit a hyperactivated phenotype with enhanced proliferation and cytokine secretion in response to IL-2 [18]. At present, the role of SPHK2 in modulating cell survival and death remains to be characterized.

Fas/CD95 is a member of the tumor necrosis factor receptor superfamily. Crosslinking Fas with its natural ligand FasL (CD178) or with agonistic antibodies induces apoptotic cell death. Fas signaling is important for elimination of selfreactive $\mathrm{T}$ and $\mathrm{B}$ lymphocytes $[19,20]$. Thus, Fas deficiency in humans and mice (e.g., during autoimmune lymphoproliferative syndrome or in $l p r$ mice) predisposes them to

*Address correspondence to this author at the Department of Hard Tissue Engineering, Biochemistry, Division of Bio-Matrix, Graduate School, Tokyo Medical and Dental University, 1-5-45 Yushima, Bunkyo, Tokyo 1138549, Japan; Tel: +81 35803 5567; Fax: +81 35803 0187;

E-mail: m.yokoyama.bch@tmd.ac.jp systemic autoimmunity. In B cells, susceptibility to Fas signaling is dramatically altered during activation [21].

Sphingolipid ceramide is known to regulate Fas-mediated cell death [22-25]. Ceramide activates a number of enzymes and contributes to membrane structure, by which it can lead to activation of caspase and induce cell death $[26,27]$. On the other hand, the ceramide-derived metabolite S1P, counteracts the action of ceramide and suppresses Fas-mediated cell death $[28,29]$. Upregulation of SPHK1 has been reported to induce Fas-resistance in B lymphoblastoid cells in case of rheumatoid arthritis [30]. However, the role of SPHK2 in Fas-mediated cell death has not been elucidated.

In the present study, we investigated the role of SPHK on Fas-mediated apoptosis. We found that the SPHK activity in A20/2J cells, a mouse B cell lymphoma cell line, is mainly due to SPHK2. Using a synthetic sphingoid analog, SG-12, previously developed as an SPHK2 inhibitor [31], we successfully demonstrated the specific involvement of SPHK2 in the suppression of Fas-dependent cell death of A20/2J cells. This effect was especially evident in the presence of BCR-crosslinking.

\section{MATERIALS AND METHODS}

\subsection{Cell Preparation and Culture}

Splenic B cells were isolated from six-week-old BALB/ cAnN mice as described previously [32]. The murine B lymphoma-derived cell line A20 and A20/2J were maintained in RPMI 1640 medium (Sigma-Aldrich, St Louis, MO) supplemented with $8 \%$ fetal bovine serum (F6178, SigmaAldrich, St Louis, MO), 2-mercaptoethanol $(50 \mu \mathrm{M})$, penicillin $(50 \mathrm{U} / \mathrm{ml})$, and streptomycin $(50 \mu \mathrm{g} / \mathrm{ml})$. Only those cells that were in exponential growth phase were used for experiments. 


\subsection{Reagents}

A compound, (2S, 3R)-2-amino-4-(4-octylphenyl)butane1-3-diol (SG-12), was prepared as previously described [31] and dissolved in DMSO at $4 \mathrm{mM}$ concentration. Anti-mouse Fas monoclonal antibody (Jo2) and FITC-annexin V were purchased from BD Pharmingen (San Diego, CA). Z-VADfmk was from the Peptide Institute (Osaka, Japan).

\subsection{Reverse Transcription Polymerase Chain Reaction (PCR)}

Total RNA was isolated from B cells, A20, and A20/2J cells using QIAzol reagent (QIAGEN) and cDNA was generated using an oligo(dT) primer and SuperScript II Reverse Transcriptase (Invitrogen). The GAPDH, SPHK1, and SPHK2 cDNAs were amplified by PCR using primers for GAPDH (5' ACCACAGTCCATGCCATCAC 3' and 5' TCCACCACCCCTGTTGCTGTA 3'), SPHK1 (5' TGCCTT CTCATTGGACTGTG 3' and 5' ACCATCAGCTCTCCA TCCAC 3') and SPHK2 (5' GGCCACCACTTATGAGGA GA 3' and 5' AGCAGTTGAGCAACAGGTCA 3'). The PCR conditions were as follows: 30 cycles; $94^{\circ} \mathrm{C}$ for $30 \mathrm{~s}$, $60^{\circ} \mathrm{C}$ for $45 \mathrm{~s}$, and $72^{\circ} \mathrm{C}$ for $60 \mathrm{~s}$.

\subsection{Plasmids and Transfection}

The pCE-puro 3x FLAG-mSPHK1a and pCE-puro 3x FLAG-mSPHK2 plasmids are derivatives of the pCE-puro vector [33] and encode the mouse SPHK1 and SPHK2 proteins, respectively. These are both tagged with a triple FLAG (3x FLAG) epitope at their N-terminus. Transfections were performed using the Nucleofector technology (Amaxa) and puromycin-resistant cells were obtained.

\subsection{SPHK Activity}

In vitro SPHK assays were performed as described previously $[1,2]$. The SPHK activity was measured in the presence of $0.25 \%$ Triton X-100 (inhibiting SPHK2) and $0.2 \mathrm{M}$ $\mathrm{KCl}$ (suitable for SPHK2). To evaluate the SPHK activity within cells, A20/2J cells were incubated with $\left[3-{ }^{3} \mathrm{H}\right]$ sphingosine after incubation with or without SG-12. Lipids were extracted and analyzed as described previously [1].

\subsection{Flow Cytometric Analysis}

A20/2J cells were stained with FITC-annexin V and propidium iodide (PI) and analyzed by flow cytometry using a FACSCalibur (BD Bioscience, Mountain View, CA). Cells were classified as live cells [Annexin $\mathrm{V}^{-} \mathrm{PI}^{-}$], apoptotic cells (Annexin $\mathrm{V}^{+} \mathrm{PI}^{-}$), and dead cells (Annexin $\mathrm{V}^{+} \mathrm{PI}^{+}$).

\subsection{Sodium Dodecyl Sulfate-Polyacrylamide Gel Elec- trophresis (SDS-PAGE) and Immunoblotting}

After stimulation, the A20/2J cells were lysed using 1\% Triton X-100 as described previously [32] in the presence of $100 \mathrm{mM} \mathrm{z}$-VAD-fmk. Proteins were separated by SDSPAGE on 10-20\% gradient gel (Wako Pure Chemical Industries, Japan) and were detected by immunoblotting with anticaspase 3 (1/2000 dilution), anti-phospho-Akt (Ser473) (1/1000 dilution), and anti-Akt (1/100 dilution) antibodies from Cell Signaling (Beverly, MA) and anti-Grb2 antibody (1/1000 dilution) from Santa Cruz Biotechnology (Santa Cruz, CA) as primary antibodies. A horseradish peroxidaseconjugated antibody was used as the secondary antibody.
Finally, immunoreactivity was determined by ECL (Amersham International, Buckinghamshire, England).

\subsection{Statistical Analysis}

Differences between mean values were assessed by a Student's t test. A $p$ value of $<0.05$ or $<0.01$ was considered statistically significant.

\section{RESULTS AND DISCUSSION}

\subsection{Sphingosine Kinase 2 (SPHK2) Mainly Contributed to SPHK Activity in A20/2J Cells}

In B cells, the expression of both SPHK1 and SPHK2 was detected (Fig. 1A). In case of SPHK2, two PCR products were observed using B cell cDNA as a template. Sequence analysis revealed that the slower migrating band contained an 83 bp insertion (data not shown). This finding suggested the presence of a splice variant of SPHK2 in B cells. Since a stop codon is present within the insertion, the splice variant would correspond to the $\mathrm{N}$-terminal one third of SPHK2. A role of such truncated form of SPHK2 should be studied in a future work. The B cell tumor line A20/2J is a subclone of the original A20 tumor cell line derived from a BALB/cAnN mouse [34]. Since A20/2J is more susceptible to Fas-dependent cell death than A20 (data not shown), we used A20/2J for the present study. SPHK2 was clearly observed, whereas that of SPHK1 was barely detectable in A20/2J cells (Fig. 1A) and A20 cells (data not shown).

The catalytic activity of SPHK2 is inhibited by high concentrations of Triton X-100 and activated in the presence of physiological concentrations of $\mathrm{KCl}$ or $\mathrm{NaCl}$ [2]. Thus, we measured SPHK activity in the presence of $0.25 \%$ Triton X100 (inhibiting SPHK2) and $0.2 \mathrm{M} \mathrm{KCl}$ (suitable for SPHK2) to evaluate relative contribution of SPHK2 over that of SPHK1. As shown in Fig. (1B) (lanes 3 and 4), S1P was generated in B cell homogenates under both the conditions. In contrast, S1P formation in the homogenates of A20/2 J cells was observed only in the presence of $0.2 \mathrm{M} \mathrm{KCl}$ (Fig. 1B, lane 2). SPHK activity under the SPHK2 assay conditions was associated with the membrane fraction (Fig. 1C). Thus, SPHK2 contributed more than SPHK1 to S1P formation in A20/2J cells as compared to B cells.

3.2. A Synthetic Sphingoid Analog Compound (SG-12), (2S, 3R)-2-Amino-4-(4-Octylphenyl)Butane-1-3-Diol, Inhibited SPHK2 Activity in A20/2J Cells

The sphingoid analog, SG-12, potently inhibits human SPHK2 but not SPHK1 activity in vitro [31]. Since SPHK2 mainly contributed to the SPHK activity in A20/2J cells, we evaluated the action of SG-12 in A20/2J cells. As shown in Fig. (2), SG-12 appreciably inhibited $\left[{ }^{3} \mathrm{H}\right] \mathrm{S} 1 \mathrm{P}$ formation. Thus, SG-12 was shown to act as a membrane-permeable inhibitor of SPHK. To confirm the action of SG-12 on SPHK2, we transfected the A20/2J cells with either mouse SPHK1 or SPHK2. The generation of $\left[{ }^{3} \mathrm{H}\right] \mathrm{S} 1 \mathrm{P}$ was not inhibited by SG-12 in SPHK1-transfected A20/2J cells, but was inhibited in SPHK2-transfected A20/2J cells (Fig. 2). However, the effect of SG-12 in SPHK2-transfected A20/2J cells was less than that in A20/2J cells. Accordingly, the results indicated that SG-12 inhibited the SPHK2 activity in A20/2J cells. 
A
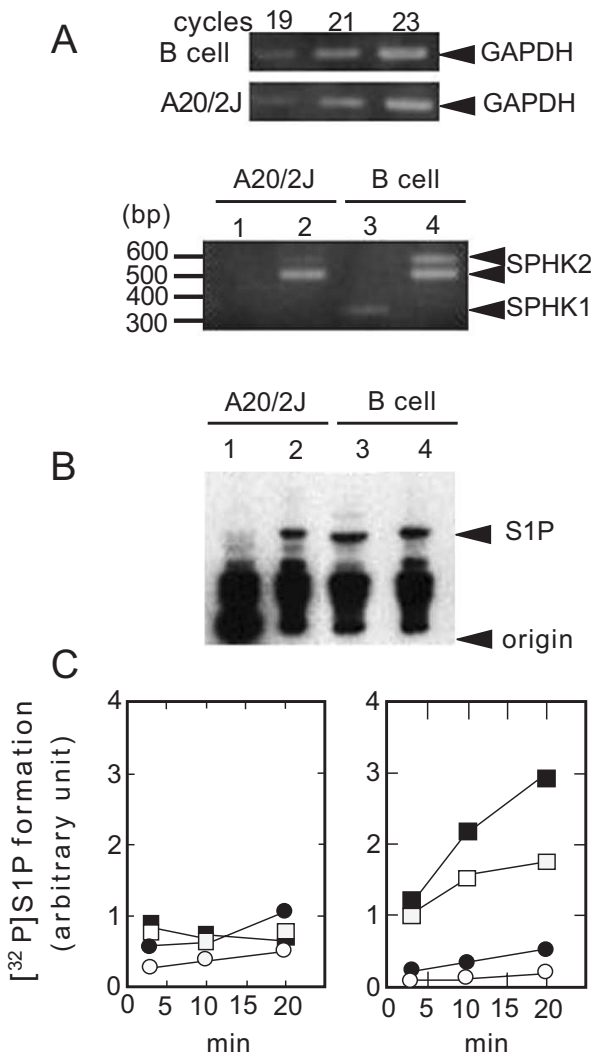

Fig. (1). SPHK2 is a major sphingosine kinase isoform in A20/2J cells. (A) Expression of SPHK1 and SPHK2 in A20/2J and mouse splenic $\mathrm{B}$ cells was detected by reverse transcription-PCR. The PCR products with cDNA from A20/2J cells (lanes 1,2) or B cells (lanes 3, 4) using primers for SPHK1 (lanes 1, 3) or SPHK2 $(2,4)$ were shown. (B) Homogenates from A20/2J cells (lanes 1, 2) and mouse splenic B cells (lanes 3,4) were incubated with sphingosine and $\left[\gamma_{-}{ }^{32} \mathrm{P}\right] \mathrm{ATP}$ in the presence of $0.25 \%$ Triton $\mathrm{X}-100$ (lanes 1,3) and $0.2 \mathrm{M} \mathrm{KCl}$ (lanes 2,4) as described in "Materials and Methods." Lipids were extracted and separated on TLC. (C) Homogenates of A20/2J cells were centrifuged at 100,000 x g for 30 min. Supernatant (open circle; $10 \mu \mathrm{g}$, open square; $40 \mu \mathrm{g}$ ) and pellet (closed circle $5 \mu \mathrm{g}$, closed square; $20 \mu \mathrm{g}$ ) fractions were incubated with sphingosine and $\left[\gamma^{32} \mathrm{P}\right] \mathrm{ATP}$ in the presence of $0.25 \%$ Triton X-100 (left panel) or $0.2 \mathrm{M} \mathrm{KCl}$ (right panel) as described in "Materials and Methods." Essentially the same result was obtained in another independent experiment.

\subsection{Effect of SG-12 on the Progression of Fas-Mediated Cell Death from Live to Apoptotic Cells}

Stimulating A20/2J cells with an anti-mouse Fas monoclonal antibody (Jo2) for $4 \mathrm{~h}$ resulted in increase in apoptotic cells (Fig. 3A). Crosslinking of BCR with an anti-mouse IgG $\mathrm{pAb}$ reduced the apoptotic cells (Fig. 3A) and inhibited the Fas-dependent activation of caspase-3 (Fig. 4B), which has been known as BCR-dependent Fas-resistance [21, 35]. A proportion of the apoptotic cells was not affected by SG-12 in the absence of BCR-crosslinking, but was increased in the presence of BCR-crosslinking (Fig. 4A). SG-12 did not produce any effects in the presence of a pan-caspase inhibitor, zVAD-fmk (Fig. 4A), suggesting that SG-12 promoted a caspase-dependent process. Activation of caspase- 3 as revealed by the appearance of its cleaved form, was slightly increased by SG-12 either in the absence or presence of BCR-crosslinking (Fig. 4B). Thus, it is suggested that the slight activation of caspase 3 by SG-12 does not directly result in the increase in apoptotic cells. Rather, it implied that SG-12 amplifies an additional process of apoptotic cell death subsequent to the activation of caspase 3 , which is evident in the presence of BCR-crosslinking.

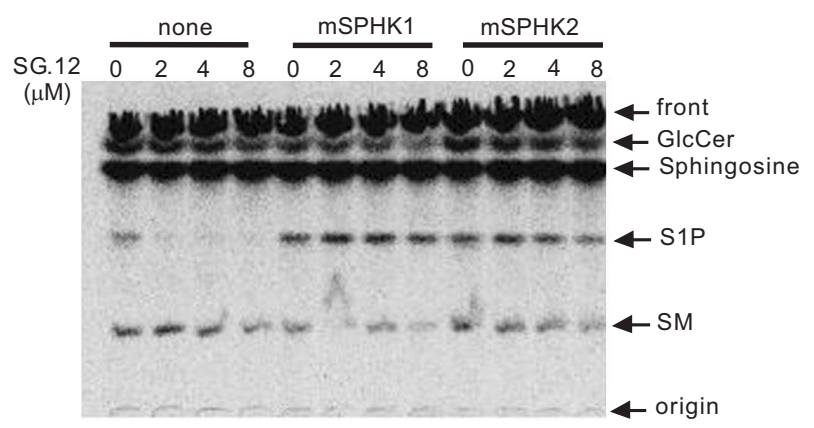

Fig. (2). The SPHK2 activity in A20/2J cells was inhibited by SG-12. A20/2J cells or A20/2J cells transfected with mouse SPHK1 or SPHK2 $\left(2 \times 10^{6}\right.$ cells $\left./ \mathrm{ml}\right)$ were incubated with or without SG-12 $(2,4,8 \mu \mathrm{M})$ for $5 \mathrm{~min}$ and then with $\left[3-{ }^{3} \mathrm{H}\right]$ sphingosine for $5 \mathrm{~min}$. Lipids were extracted and separated by TLC as described in "Materials and Methods." $\left[{ }^{3} \mathrm{H}\right]$ Ceramide and $\left[{ }^{3} \mathrm{H}\right]$ palmitic acid moved with solvent front. Essentially the same result was obtained in another independent experiment.

A

\begin{tabular}{|c|c|c|c|c|c|c|c|}
\hline Anti-Fas & - & & - & & + & & $t$ \\
\hline Anti-IgG & - & & + & & - & & + \\
\hline $\begin{array}{l}10^{4} \\
10^{3}\end{array}$ & $\begin{array}{c}2.43 \\
\end{array}$ & $-^{0.14}$ & $\begin{array}{l}2.06 \\
\end{array}$ & 0.09 & 1.02 & 0.20 & 1.73 \\
\hline $\begin{array}{l}10^{2}-85.7 \\
10^{1}- \\
10^{0}\end{array}$ & 11.8 & & 18.6 & 32.7 & 66.2 & -49.8 & 48.3 \\
\hline
\end{tabular}

$\mathrm{B}$

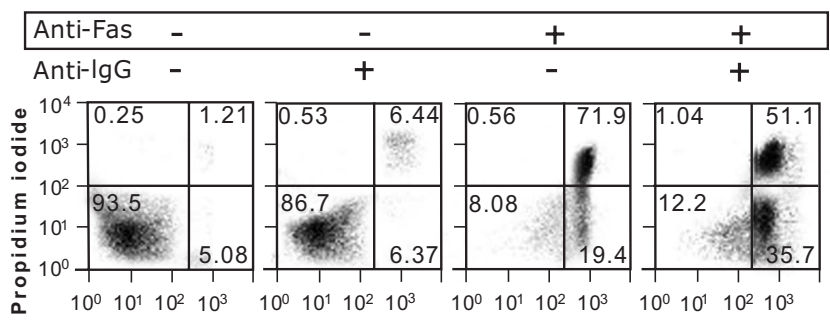

FITC-Annexin V

Fig. (3). Progression of Fas-mediated cell death in A20/2J cells. A20/2J cells $\left(1 \times 10^{6}\right.$ cells $\left./ \mathrm{ml}\right)$ were incubated without or with 100 $\mathrm{ng} / \mathrm{ml}$ anti-mouse Fas $\mathrm{mAb}$ or $5 \mu \mathrm{g} / \mathrm{ml} \mathrm{F}\left(\mathrm{ab}^{\prime}\right)_{2}$ of anti-mouse $\mathrm{IgG}$ pAb for $4 \mathrm{~h}$ (A) or $20 \mathrm{~h}$ (B) and analyzed using flow cytometry as described under "Materials and methods."

The effect of SG-12 could be explained by an impairment of BCR-signaling. However, a BCR-dependent inhibition of caspase 3-activation was clearly observed in the presence of SG-12 (Fig. 3B). In addition, an activation of PI3K as revealed by the phosphorylation of Akt, which mediates the suppressive effect of BCR-crosslinking on Fas-dependent 
cell death [35], was inhibited by LY294002 but not by SG12 (Fig. 4C). Therefore, the effect of SG-12 in increasing in apoptotic cells may be highlighted when the increase in apoptotic cells is retarded by BCR-crosslinking.
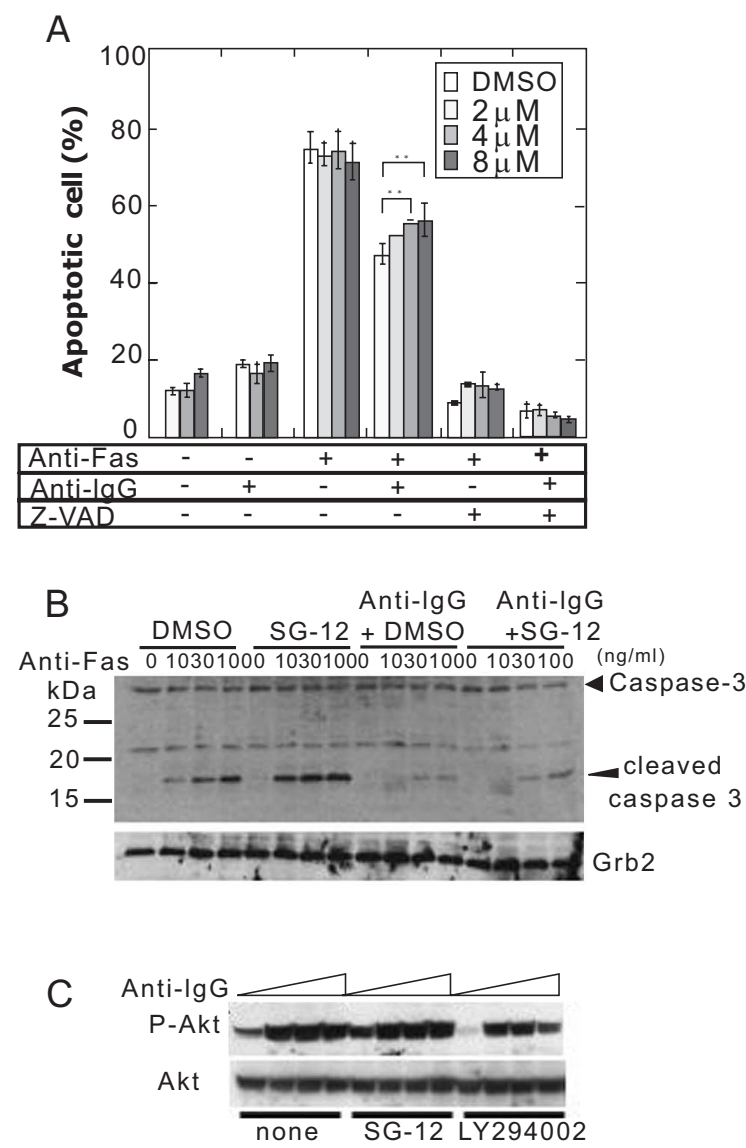

Fig. (4). SG-12 promoted the progression of early stage of Fasmediated cell death. (A) A20/2J cells $\left(1 \times 10^{6}\right.$ cells $\left./ \mathrm{ml}\right)$ were incubated without or with $100 \mathrm{ng} / \mathrm{ml}$ anti-mouse Fas mAb, $5 \mu \mathrm{g} / \mathrm{ml}$ $\mathrm{F}(\mathrm{ab})_{2}$ of anti-mouse IgG pAb, or $50 \mu \mathrm{M} \mathrm{z}$-VAD-fmk in the presence or absence of SG-12 for $4 \mathrm{~h}$. Fractions of apoptotic cells (Annexin $\mathrm{V}^{+} \mathrm{PI}^{-}$) are shown. Values are means $\pm \mathrm{SD}$ from triplicate samples. Statistically significant differences $(* * p<0.01)$ with respect to the values without SG-12 are indicated. (B) A20/2J cells (1 x $10^{6}$ cells $/ \mathrm{ml}$ ) were incubated without or with anti-mouse Fas mAb and $5 \mu \mathrm{g} / \mathrm{ml} \mathrm{F}\left(\mathrm{ab}^{\prime}\right)_{2}$ of anti-mouse IgG pAb in the presence or absence of $8 \mu \mathrm{M} \mathrm{SG}-12$. After $4 \mathrm{~h}$, cells were lysed and proteins were detected by immunoblotting as described in "Materials and Methods." (C) A20/2J cells $\left(1 \times 10^{8}\right.$ cells $\left./ \mathrm{ml}\right)$ were preincubated without or with $8 \mu \mathrm{M}$ SG-12 or $4 \mu \mathrm{M}$ LY294002 for $5 \mathrm{~min}$ and stimulated with an $\mathrm{F}\left(\mathrm{ab}^{\prime}\right)_{2}$ of an anti-mouse $\operatorname{IgG} \mathrm{pAb}(2.5,5,10 \mu \mathrm{g} / \mathrm{ml})$ for 5 min. Then, the cells were lysed and proteins were detected by immunoblotting as described in "Materials and Methods." Essentially the same result was obtained in another independent experiment.

\subsection{Effect of SG-12 on the Progression of Fas-Mediated Cell Death from Apoptotic to Dead Cells}

Next, we focused on the effect of SG-12 during the late stages of cell death, from visible apoptosis to dead cells. After Fas stimulation for $20 \mathrm{~h}$, most cells became positive for Annexin V and BCR-crosslinking resulted in a decrease in dead cells and an increase in apoptotic cells (Fig. 3B). As shown in Fig. (5A), the proportions of live, apoptotic, and dead cells were not affected by SG-12 in the absence of BCR-crosslinking. In contrast, the proportion of apoptotic cells was reduced and that of dead cells was increased by SG-12 in the presence of BCR-crosslinking (Fig. 5B). It should be noted that, when the cells were stimulated with an anti-Fas antibody at concentrations higher than $10 \mathrm{ng} / \mathrm{ml}$ and in the presence of BCR-crosslinking, the levels of apoptotic and dead cells did not change (at around 35\% and 50\%, respectively), while the initial activation of caspase 3 was increased (Fig. 5D). This observation suggested that BCRcrosslinking causes a pause in the progression of cells from apoptotic stage to death: addition of SG-12 relieved this pause.

\begin{tabular}{|llc|}
\hline & \multicolumn{2}{c|}{ SG-12 } \\
Live & $\circ$ & $\bullet$ \\
Apoptotic & $\Delta$ & $\Delta$ \\
Dead & $\square$ & \\
\hline
\end{tabular}
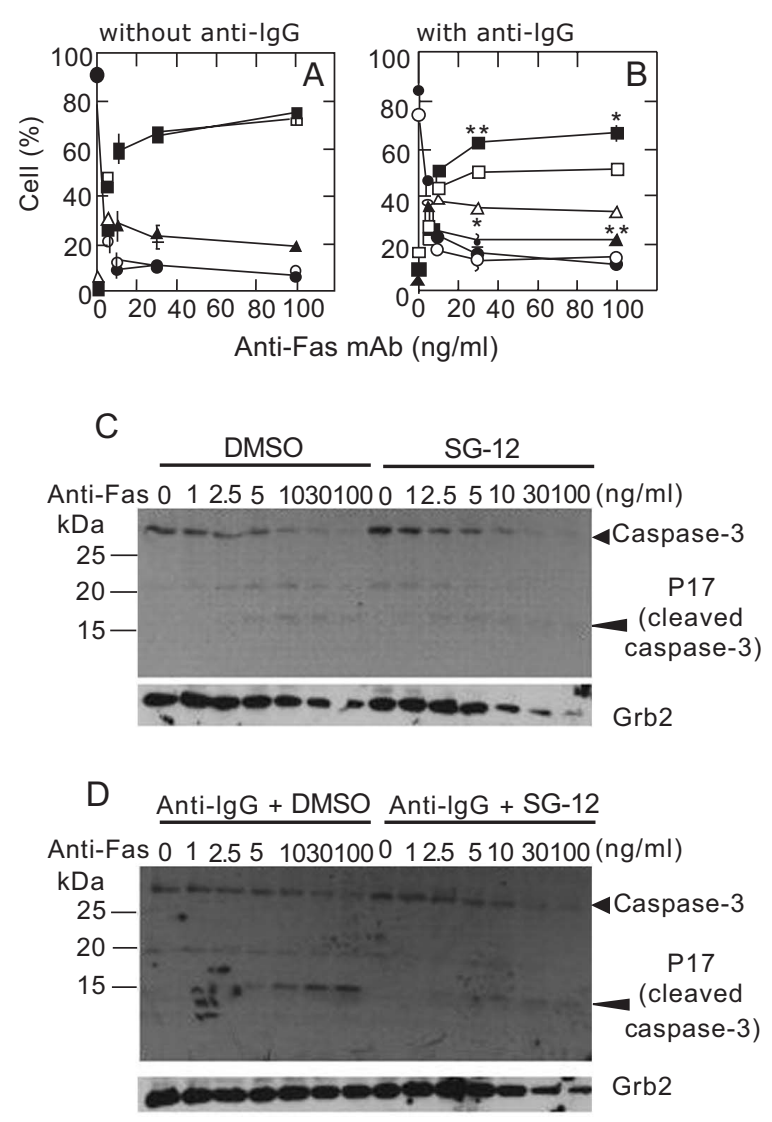

Fig. (5). SG-12 promoted the progression of late stage of Fasmediated cell death. $(\mathbf{A}, \mathbf{B}) \mathrm{A} 20 / 2 \mathrm{~J}$ cells $\left(1 \times 10^{6}\right.$ cells $\left./ \mathrm{ml}\right)$ were incubated without or with anti-mouse Fas mAb or $8 \mu \mathrm{M} \mathrm{SG}-12$ for $20 \mathrm{~h}$ in the absence (A) or presence (B) of $5 \mu \mathrm{g} / \mathrm{ml}$ anti-mouse $\mathrm{IgG}$ $\mathrm{pAb}$. Values are means \pm SD from triplicate samples. Statistically significant differences $(* p<0.05$ or $* * p<0.01)$ with respect to the values without SG-12 are indicated. Results are representative of four independent experiments. (C, D) A20/2J cells $\left(1 \times 10^{6}\right.$ cells $/ \mathrm{ml}$ ) were incubated without or with anti-mouse Fas mAb without (C) or with (D) $5 \mu \mathrm{g} / \mathrm{ml} \mathrm{F}\left(\mathrm{ab}^{\prime}\right)_{2}$ of anti-mouse IgG pAb in the presence or absence of $8 \mu \mathrm{M} \mathrm{SG}-12$. After $20 \mathrm{~h}$, the cells were lysed and their proteins were detected by immunoblotting as described in "Materials and Methods." Essentially the same result was obtained in another independent experiment. 
An active form of caspase 3 (p17) was hardly detected in the absence of BCR-crosslinking after Fas stimulation for 20 $\mathrm{h}$ (Fig. 5C). On the other hand, p17 remained in the presence of BCR-crosslinking; however, it almost disappeared following the addition of SG-12 (Fig. 5D). Since a cytosolic protein, Grb2, was also decreased after Fas-stimulation, it is conceivable that $\mathrm{p} 17$ is released from dead cells due to a damage of plasma membranes. It should be noted that SG-12 promoted the decrease in Grb2 both in the absence (Fig. 5C) and presence (Fig. 5D) of BCR-crosslinking, whereas SG-12 did not affect the Fas-dependent decrease in uncleaved caspase 3. It implied that the addition of SG-12 promotes the progression of late stage cell death after activation of caspase 3.

Collectively, SG-12 accelerated both early and late stages of Fas-mediated cell death as shown by the exposure of phosphatidylserine (annexin V-staining) and the change of membrane permeability (PI-staining), respectively.

\subsection{Effect of SG-12 on the Progression of Fas-Mediated Cell Death in A20/2J Cells Transfected with SPHK1 or SPHK2}

To confirm the involvement of SPHK2 in reactions mediated by SG-12, we used SPHK1- and SPHK2-transfected A20/2J cells (Fig. 6). SG-12 decreased the apoptotic cells and increased the dead cells after a $20 \mathrm{~h}$ Fas stimulation, in the presence of BCR-crosslinking in A20/2J cells (Fig. 6B) and in SPHK1-transfected A20/2J cells (Fig. 6D). In contrast, in SPHK2-transfected A20/2J cells (Fig. 6F), SG-12 did not increase the dead cells. A slight SG-12 mediated decrease in apoptotic cells may reflect an increase of live cells, however, we did not investigate this point further in the present study. The results indicated that the effect of SG-12 in promoting progression of Fas-dependent cell death progression is closely related to SPHK2.

\section{CONCLUSION}

An SK2 inhibitor compound, SG-12, enabled us to demonstrate the involvement of SPHK2 in the suppression of Fas-dependent cell death in A20/2J cells. Interestingly, SG12 was able to accelerate the progression of late stage cell death indicators such as a change in membrane permeability, probably due to disruption of membrane integrity. This effect was especially evident in the presence of BCRcrosslinking. Although many previous studies focused on the initiation of cell death, i.e., caspase activation, the regulation of the late stages of cell death remains largely unclear. Our results implied the potential ability of SHK2 to suppress the progression of late stage Fas-mediated cell death.

The ability of SG-12 to inhibit S1P formation in A20/2J cells was diminished by SPHK1 transfection (Fig. 2). But SPHK1 transfection did not relieve the effect of SG-12 on the progression of cell death (Fig. 6). Thus, the generation of $\mathrm{S} 1 \mathrm{P}$ per se, may not be sufficient to suppress Fas-mediated cell death. On the other hand, it has been previously reported that the generation of ceramide is increased by SPHK2 but decreased by SPHK1 [36]. SPHK2 probably facilitates the S1P-mediated salvage pathway of ceramide synthesis in which S1P is dephosphorylated to sphingosine by S1Pphosphatase and then acylated to form ceramide in ER [37]. Corroborating previous findings, the generation of the $\left[{ }^{3} \mathrm{H}\right]$ ceramide-derived metabolites, $\left[{ }^{3} \mathrm{H}\right] \mathrm{GlcCer}$ and $\left[{ }^{3} \mathrm{H}\right]$ sphingomyelin, in $\left[{ }^{3} \mathrm{H}\right]$ sphingosine-labeled A20/2J cells were increased by SPHK2 transfection and decreased by SG-12 (Fig. 2). Previously, it has been reported that the generation of ceramide is involved in cell death in B cells [38, 39]. Further study is necessary to correlate such SPHK2-mediated sphingolipid metabolism and the regulation of cell death. \begin{tabular}{lll}
\hline & Live $\triangle$ Apoptotic $\square$ Dead
\end{tabular}
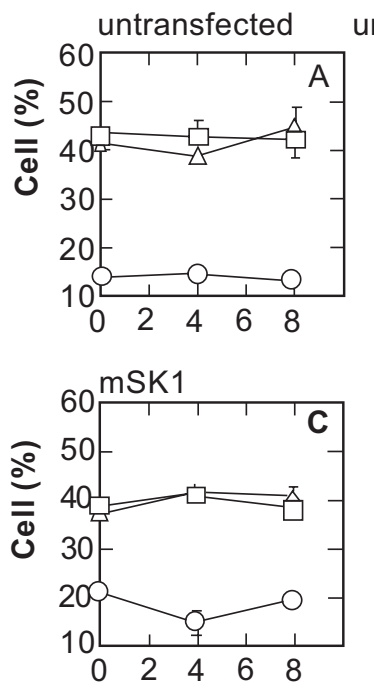

ntransfected + anti-lgG
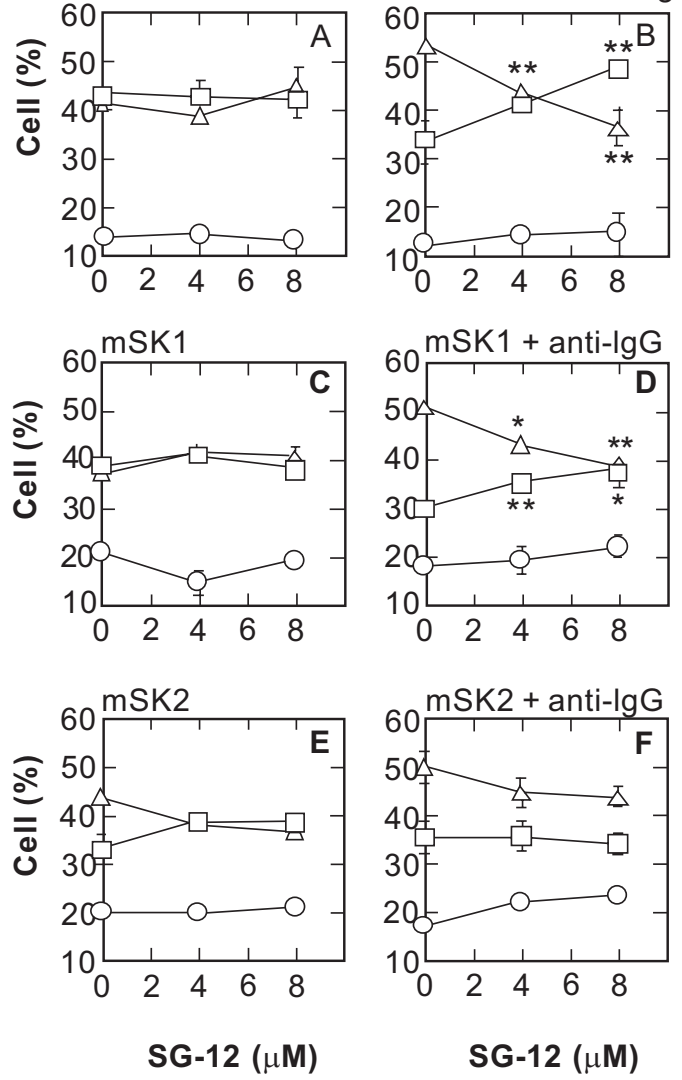

Fig. (6). Effect of SG-12 on Fas-mediated cell death was relieved by transfection of SPHK2 but not SPHK1. A20/2J cells (A, B) or the cells transfected with SPHK1 (C, D) or SPHK2 (E, F) were incubated with $100 \mathrm{ng} / \mathrm{ml}$ anti-mouse Fas $\mathrm{mAb}$ for $20 \mathrm{~h}$ without (A, $\mathbf{C}, \mathbf{E})$ or with $(\mathbf{B}, \mathbf{D}, \mathbf{F}) 5 \mu \mathrm{g} / \mathrm{ml} \mathrm{F}\left(\mathrm{ab}^{\prime}\right)_{2}$ of anti-mouse $\mathrm{IgG} \mathrm{pAb}$ in the presence of indicated concentrations of SG-12. Values are means \pm SD from triplicate samples. Statistically significant differences $(* \mathrm{p}<0.05$ or $* * \mathrm{p}<0.01)$ with respect to the values without SG-12 are indicated. Essentially the same result was obtained in an independent experiment.

\section{ACKNOWLEDGEMENTS}

We thank Dr. Takuma Nakajima and Dr. Katarzyna A. Podyma-Inoue (Tokyo Medical and Dental University) for their valuable discussion. This work was supported by the Grants-in-Aids for $21^{\text {st }}$ Century COE Program to Tokyo Medical and Dental University from the Ministry of Education, Science, Sports and Culture, Japan.

\section{ABBREVIATIONS}

$\begin{array}{lll}\text { SPHK } & = & \text { Sphingosine kinase } \\ \mathrm{S} 1 \mathrm{P} & = & \text { Sphingosine-1-phosphate } \\ \mathrm{BCR} & = & \mathrm{B} \text { cell receptor }\end{array}$


$\begin{aligned} \mathrm{SG}-12= & (2 \mathrm{~S}, 3 \mathrm{R})-2 \text {-amino-4-(4-octylphenyl)butane- } \\ & \text { 1-3-diol }\end{aligned}$

PI $=$ Propidium iodide

\section{REFERENCES}

[1] Kohama, T.; Olivera, A.; Edsall, L.; Nagiec, M.M.; Dickson, R.; Spiegel, S. J. Biol. Chem., 1998, 273, 23722-23728.

[2] Liu, H.; Sugiura, M.; Nava, V.E.; Edsall, L.C.; Kono, K.; Poulton, S.; Milstien, S.; Kohama, T.; Spiegel, S. J. Biol. Chem., 2000, 275, 19513-19520.

[3] Spiegel, S.; Milstien, S. J. Biol. Chem., 2007, 282, 2125-2129.

[4] Allende, M.L.; Sasaki, T.; Kawai, H.; Olivera, A.; Mi, Y.; van Echten-Deckert, G.; Hajdu, R.; Rosenbach, M.; Keohane, C. A.; Mandala, S.; Spiegel, S.; Proia, R.L. J. Biol. Chem., 2004, 279, 52487-52492.

[5] Kharel, Y.; Lee, S.; Snyder, A.H.; Sheasley-O'neill S.L.; Morris, M.A.; Setiady, Y.; Zhu, R.; Zigler, M.A.; Burcin, T.L.; Ley, K.; Tung, K.S.; Engelhard, V.H.; Macdonald, T.L.; Pearson-White, S.; Lynch, K.R. J. Biol. Chem., 2005, 280, 36865-36872.

[6] Mizugishi, K.; Yamashita, T.; Olivera, A.; Miller, G.F.; Spiegel, S.; Proia, R.L. Mol. Cell Biol., 2005, 25, 11113-11121.

[7] Wang, F.; Van Brocklyn, J.R.; Hobson, J.P.; Movafagh, S.; Zukowska-Grojec, Z.; Milstien, S.; Spiegel, S. J. Biol. Chem., 1999, 274, 35343-35350.

[8] Lee, M.J.; Thangada, S.; Claffey, K.P.; Ancellin, N.; Liu, C.H.; Kluk, M.; Volpi, M.; Sha'afi, R.I.; Hla, T. Cell, 1999, 99, 301-312.

[9] English, D.; Welch, Z.; Kovala, A.T.; Harvey, K.; Volpert, O.V.; Brindley, D.N.; Garcia, J.G. FASEB J., 2000, 14, 2255-2265.

[10] Liu, Y.; Wada, R.; Yamashita, T.; Mi, Y.; Deng, C.X.; Hobson, J. P.; Rosenfeldt, H.M.; Nava, V.E.; Chae, S.S.; Lee, M.J.; Liu, C.H.; Hla, T.; Spiegel, S.; Proia, R.L. J. Clin. Invest., 2000, 106, 951961.

[11] Okamoto, H.; Takuwa, N.; Yokomizo, T.; Sugimoto, N.; Sakurada, S.; Shigematsu, H.; Takuwa, Y. Mol. Cell Biol., 2000, 20, 92479261.

[12] Kupperman, E.; An, S.; Osborne, N.; Waldron, S.; Stainier, D.Y. Nature, 2000, 406, 192-195.

[13] Graeler, M.; Shankar, G.; Goetzl, E.J. J. Immunol., 2002, 169, 4084-4087.

[14] Hait, N.C.; Oskeritzian, C.A.; Paugh, S.W.; Milstien, S.; Spiegel, S. Biochim. Biophys. Acta, 2006, 1758, 2016-2026.

[15] Olivera, A.; Rosenfeldt, H.M.; Bektas, M.; Wang, F.; Ishii, I.; Chun, J.; Milstien, S.; Spiegel, S. J. Biol. Chem., 2003, 278, 4645246460.

[16] Liu, H.; Toman, R.E.; Goparaju, S.K.; Maceyka, M.; Nava, V.E.; Sankala, H.; Payne, S.G.; Bektas, M.; Ishii, I.; Chun, J.; Milstien, S.; Spiegel, S. J. Biol. Chem., 2003, 278, 40330-40336.
[17] Igarashi, N.; Okada, T.; Hayashi, S.; Fujita, T.; Jahangeer, S.; Nakamura, S. J. Biol. Chem., 2003, 278, 46832-46839.

[18] Samy, E.T.; Meyer, C.A.; Caplazi, P.; Langrish, C.L.; Lora, J.M.; Bluethmann, H.; Peng, S. L. J. Immunol., 2007, 179, 5644-5648.

[19] Van Parijs, L.; Abbas, A.K. Curr. Opin. Immunol., 1996, 8, 355361.

[20] Siegel, R.M.; Chan, F.K.; Chun, H.J.; Lenardo, M.J. Nat. Immunol., 2000, $1,469-474$.

[21] Mizuno, T.; Zhong, X.; Rothstein, T.L. Apoptosis, 2003, 8, 451460.

[22] Jarvis, W.D.; Grant, S. Curr. Opin. Oncol., 1998, 10, 552-559.

[23] Watanabe, M.; Kitano, T.; Kondo, T.; Yabu, T.; Taguchi, Y.; Tashima, M.; Umehara, H.; Domae, N.; Uchiyama, T.; Okazaki, T. Cancer Res., 2004, 64, 1000-1007.

[24] Grassme, H.; Cremesti, A.; Kolesnick, R.; Gulbins, E. Oncogene, 2003, 22, 5457-5470.

[25] Miyaji, M.; Jin, Z.X.; Yamaoka, S.; Amakawa, R.; Fukuhara, S.; Sato, S.B.; Kobayashi, T.; Domae, N.; Mimori, T.; Bloom, E.T.; Okazaki, T.; Umehara, H. J. Exp. Med., 2005, 202, 249-259.

[26] Hannun, Y.A. J. Biol. Chem., 1994, 269, 3125-3128.

[27] Ruvolo, P.P. Pharmacol. Res., 2003, 47, 383-392.

[28] Cuvillier, O.; Pirianov, G.; Kleuser, B.; Vanek, P.G.; Coso, O.A.; Gutkind, S.; Spiegel, S. Nature, 1996, 381, 800-803.

[29] Bektas, M.; Jolly, P.S.; Muller, C.; Eberle, J.; Spiegel, S.; Geilen, C. C. Oncogene, 2005, 24, 178-187.

[30] Pi, X.; Tan, S.Y.; Hayes, M.; Xiao, L.; Shayman, J.A.; Ling, S.; Holoshitz, J. Arthritis Rheum., 2006, 54, 754-764.

[31] Kim, J.W.; Kim, Y.W.; Inagaki, Y.; Hwang, Y.A.; Mitsutake, S.; Ryu, Y.W.; Lee, W.K.; Ha, H.J.; Park, C.S.; Igarashi, Y. Bioorg. Med. Chem., 2005, 13, 3475-3485.

[32] Hara-Yokoyama, M.; Kimura, T.; Kaku, H.; Wakiyama, M.; Kaitsu, Y.; Inoue, M.; Kusano, S.; Shirouzu, M.; Yokoyama, S.; Katada, T.; Hirabayashi, Y.; Takatsu, K.; Yanagishita, M. Int. Immunopharmacol., 2008, 8, 59-70.

[33] Kihara, A.; Ikeda, M.; Kariya, Y.; Lee, E.Y.; Lee, Y.M.; Igarashi, Y. J. Biol. Chem., 2003, 278, 14578-14585.

[34] McKean, D.J.; Infante, A.J.; Nilson, A.; Kimoto, M.; Fathman, C.G.; Walker, E.; Warner, N. J. Exp. Med., 1981, 154, 1419-1431.

[35] Moriyama, H.; Yonehara, S. Immunol. Lett., 2007, 109, 36-46.

[36] Maceyka, M.; Sankala, H.; Hait, N.C.; Le Stunff, H.; Liu, H.; Toman, R.; Collier, C.; Zhang, M.; Satin, L.S.; Merrill, A.H., Jr.; Milstien, S.; Spiegel, S. J. Biol. Chem., 2005, 280, 37118-37129.

[37] Le Stunff, H.; Galve-Roperh, I.; Peterson, C.; Milstien, S.; Spiegel, S. J. Cell Biol., 2002, 158, 1039-1049.

[38] Kroesen, B.J.; Pettus, B.; Luberto, C.; Busman, M.; Sietsma, H.; de Leij, L.; Hannun, Y.A. J. Biol. Chem., 2001, 276, 13606-13614.

[39] Kroesen, B.J.; Jacobs, S.; Pettus, B.J.; Sietsma, H.; Kok, J.W.; Hannun, Y.A.; de Leij, L.F. J. Biol. Chem., 2003, 278, 1472314731 . 